University for Business and Technology in Kosovo

UBT Knowledge Center

UBT International Conference

2018 UBT International Conference

Oct 27th, 9:00 AM - 10:30 AM

\title{
An aplication of MCDA method to evaluate and select the most suitable landfill sites for urban waste. A project case study for Berat County. Albania
}

\author{
Robert Kosova \\ Aleksander Moisiu University, robertko60@yahoo.com \\ Fabiana Cullhaj \\ Aleksander Moisiu University \\ Teuta Thanasi \\ Aleksander Moisiu University \\ Arben Reka \\ Aleksander Moisiu University \\ Taulant Kullolli \\ Aleksander Moisiu University
}

See next page for additional authors

Follow this and additional works at: https://knowledgecenter.ubt-uni.net/conference

Part of the Engineering Commons

\section{Recommended Citation}

Kosova, Robert; Cullhaj, Fabiana; Thanasi, Teuta; Reka, Arben; Kullolli, Taulant; and Thanasi, Gjergji, "An aplication of MCDA method to evaluate and select the most suitable landfill sites for urban waste. A project case study for Berat County. Albania" (2018). UBT International Conference. 143.

https://knowledgecenter.ubt-uni.net/conference/2018/all-events/143

This Event is brought to you for free and open access by the Publication and Journals at UBT Knowledge Center. It has been accepted for inclusion in UBT International Conference by an authorized administrator of UBT Knowledge Center. For more information, please contact knowledge.center@ubt-uni.net. 


\section{Presenter Information}

Robert Kosova, Fabiana Cullhaj, Teuta Thanasi, Arben Reka, Taulant Kullolli, and Gjergji Thanasi 


\title{
An aplication of MCDA method to evaluate and select the most suitable landfill sites for urban waste. A project case study for Berat County. Albania.
}

\author{
Robert Kosova, Fabiana Cullhaj, Teuta Thanasi, Arben Reka, \\ Taulant Kullolli, Gjergji Thanasi \\ University "Aleksandër Moisiu". Durrës. Albania. \\ robertko60@yahoo.com
}

\begin{abstract}
Waste management system needs a clear and strict management policy. They also need a process of evaluating and selecting the most appropriate landfill sites that respect the restrictions and constraints dictated by the presence of the population in that area, with respect to ecological ecosystems and other factors. In addition to the geographical and geological criteria and other specifications that are defined by traditional selection procedures, there are new factors adding to the old constraints and limitations. Urban waste is produced in large quantities in our cities, every year. As a result, the number of sites should increase with the population growth as well as the increase in urban waste products. On the other hand, the eligibility criteria and adding constraints and limitations make it more difficult to choose suitable sites. Environmental and local and state regulations limit the number of choices as well as areas and volume of sites making their selection more difficult, posing a real challenge for specialists. Specialists need to use the Geographic Information System (GIS) as well as the method of Multiple Critical Decision Analysis (MCDA) to select the most optimal location. Our study aims to apply MCDA integrated with GIS to select potential sites for urban waste deposition. The method of hierarchy analysis (AHP) will be used to weight and rank the constraints and criteria. This article is part of a potential project we are working to propose to Berat County, Albania.
\end{abstract}

Keywords: site, landfill, mcda, criteria, AHP 


\section{Introduction}

The problem of waste and urban waste is a growing concern all over the world, especially in poor and developing countries. However, it is a major problem for countries that do not have a clear policy on urban waste management that includes and respect all social, economic, political and environmental factors.

Reducing waste production, increasing the amount or percentage of recycling, processing, waste transformation are widely used methods by countries that have achieved an efficient management of the problem. Beyond the methods of recycling waste, incineration or dumping, the method of underground deposition is referred to landfilling. The process of choosing the suitable landfill is a difficult task because it requires many criteria, policies and restrictions to be respected, and it depends on different factors and regulators, whether these political, social, economic, etc.

Increasing populations and population density, increasing public health concerns, increasing new urban centres, roads and water pipes will make the construction of landfills very difficult, but not impossible.

Pollution of surface and groundwater are the main long- term problems that are closely related to the environment and the health of the population because there is a great risk of the possibility of contamination of surface water and underground waste from urban waste deposits. These are main concerns a team of specialist should consider before they start looking for the landfill sites.

\section{Methods and Methodology MCDA and AHP.}

The process of selecting the most suitable sites for depositing urban waste is a process that needs to take into account several factors that are of geological, social, ecological, economical, etc.

From a geological point of view, sites suitable for landfill projects are subject to serious criteria to make sure that the effects of pollution, particularly groundwater pollution, are minimized, [1]. Factors that determine the suitability of geological and hydrogeological sites are:

1. Layer lithology (rock type, stone size characteristics, texture, bed characteristics), geology (rock thickness, homogeneity), hydrology (porosity, permeability), geological structure, (bedding, folding, defects), hydrogeology (groundwater levels, water distribution, water flow), surface (size and discharge of passages passing through the site), topography (steep slope, wind, visual impact, etc.).

The technical decision for the most appropriate landfill assessment needs specialists of different fields to work together, using multiple criteria analysis method (MCDA) as well as geographic information system (GIS).

For this purpose, six sites are selected, including the present site. From the first selection, two sites are excluded due to the failure of geological criteria.

To estimate the sites, 12 inputs or criteria are used. They are urban centres, land use, pipes, power lines, roads, surface water, slope, streams, surface water, industrial areas, liquid gas pipes, soil types. AHP will be used to weight all the factors in order to evaluate the sites. AHP uses the pairwise comparison to ranking all the factors. 


\subsection{Multi-criteria decision analysis techniques. AHP.}

Multi-criteria decision analysis, (MCDA) is a sub- discipline of operations research, [2]. AHP method, (Saaty 1977, 1980 \& Saaty and Vargas, 1991) is a well-known method in MCDA, [3]. In this method, both quantitative and qualitative information about decision-making problems can be organized. AHP is a flexible, quantitative method for selecting among alternatives which are based on their relative performance to more than one interest criteria. Criteria weight can be defined as a value assigned to each factor which indicates its relative importance to other factors under consideration, fig. 1. There are four different techniques when assigning the weights: ranking, rating, pairwise comparison and trade of analysis methods. Pairwise comparison method has advantages. For each comparison, we decide which of the two criteria is more important and assign a score which shows how much more important to other criteria, table 1. MCDA applications have been very useful in strategic planning and choices, industrial project assessments such as investment

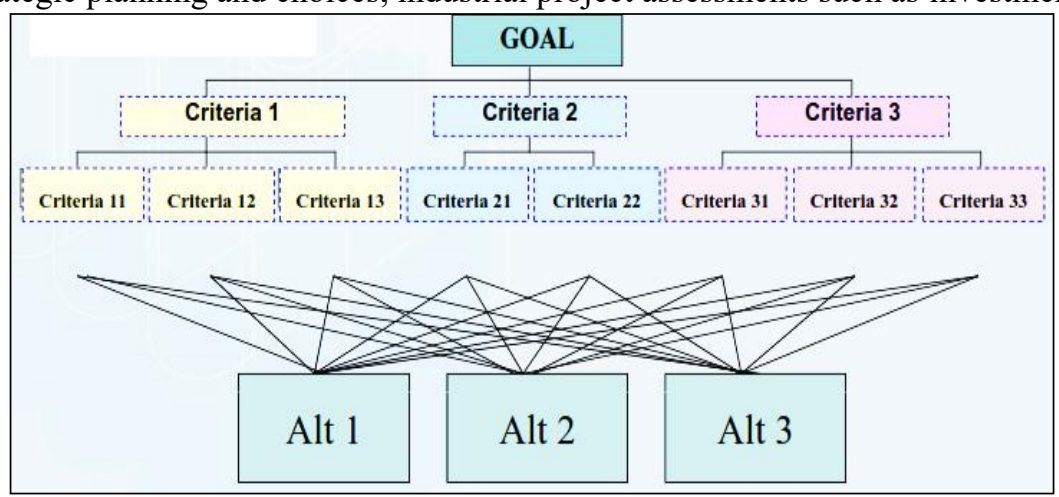

priorities, technology choices, tourism development priorities, technological services estimates, etc. Some of its most popular applications are;

- Choosing a Cooler System for a Power Plant- France,

- Localization of Wind Farm Project- France,

- Personal Financial Planning- Germany,

- Bank Rating- Greece,

- Cost Evaluation of Nuclear Fuel Repository- Belgium

- Composite Web Site Selection- France.

Fig.1

Table 1.

\begin{tabular}{|l|l|}
\hline \multicolumn{2}{|c|}{ Scale for the comparison (Saaty and Vargas), 1991} \\
\hline Scale & Degree of preference \\
\hline
\end{tabular}




\begin{tabular}{|l|l|}
\hline 1 & Equal importance \\
\hline 3 & Moderate importance \\
\hline 5 & Strong importance of one factor over another \\
\hline 7 & Very strong importsnce \\
\hline 9 & Extreme importance \\
\hline $2,4,6,8$ & Values for inverse comparison \\
\hline
\end{tabular}

\section{3 Buffer Zones.}

1) Residential Areas.

According to Allen, et al. [4], the distance from the residential areas should be at least $5 \mathrm{~km}$ and from isolated houses $500 \mathrm{~m}$ to find a landfill.

The buffer zone for a population of more than 500 people was defined as $1000 \mathrm{~m}$. For other centres is $500 \mathrm{~m}$, for private residences, businesses, community and social buildings is $250 \mathrm{~m}$.

2) Industrial Areas.

The minimum distance, [5], to the study area was defined as $5 \mathrm{~km}$ for residential areas and $250 \mathrm{~m}$ for industrial areas. The industrial zone layer is classified as appropriate or inappropriate by defining values 1 and 0 respectively.

3) Roads

The minimum distance from the urban or urban transport network is $100 \mathrm{~m}$ on both sides, [6]. All roads involving main, middle, regional and third class roads should be avoided at least $30 \mathrm{~m}$ from both sides. A distance greater than $1 \mathrm{~km}$ from main roads and highways should be provided.

4) Airports.

A distance of 10 to $13 \mathrm{~km}$ should be called a safe distance from the flight zone. Taking into account these estimates, it is designated as safe distance from the airport at a distance of $3000 \mathrm{~m}$. Areas were rated as appropriate for value 1 and not worth 0 .

5) Surface waters.

The required protection zone for swamp areas is defined as $250 \mathrm{~m}$.

6) Pipelines.

Pipelines taken into account are those of the water supply of the population. The security zone is up to a distance of $250 \mathrm{~m}$ on both sides. The area is called appropriate or inappropriate by giving values of 1 or 0 .

7) Energy lines.

The security zone is $30 \mathrm{~m}$ on both sides of the line. The power line layer is classified as appropriate for the site by setting values 1 and 0 respectively.

8) Water currents, streams, rivers.

The necessary water currents area is $300 \mathrm{~m}$ on both sides, [7]. The surface water layer has been classified as appropriate for a waste disposal site with values of 0 and 1 .

9) Liquid gas tubes.

The indispensable buffer zone for liquid gas pipes is defined as $300 \mathrm{~m}$.

10) Use of land. 
Types of land use are grouped and evaluated according to their suitability for a site of urban waste deposition giving values 0,5 and 10 .

\section{Study Area.}

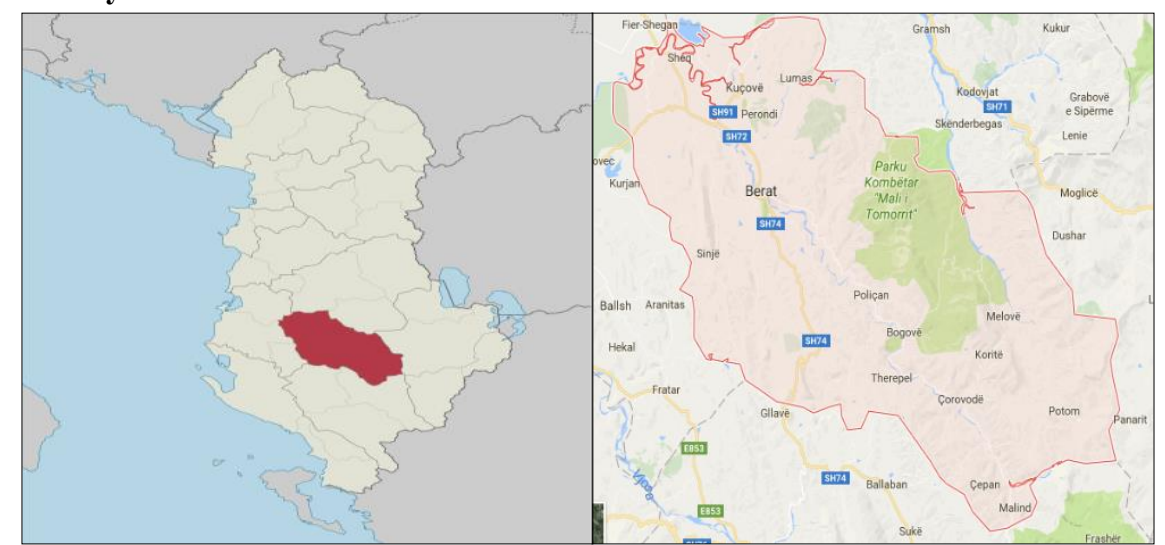

Berat County is located in southwest of Albania, the coordinates are:

North 40 degrees 52'24 "; $\quad$ South 40 degrees 29'30 “"

East 20 degrees 10'51 "; $\quad$ West 19 degrees 44'30 ".

County covers an area of 1.6 square km city), fig. 2,3 .

Berat is one of the oldest cities in Albania, more than 2400 years ago. The first archaeological finds date back to $400 \mathrm{BC}$. This makes it a very important city from the tourist and cultural point of view, and a very popular destination for foreign tourists.

Fig. 2

Fig. 3.

The population has been reduced due to internal or external emigration, during the years 2003-2018. However, urban waste production has been increased because of higher standart of living, consumption, construction, tourism, urban development, etc, table

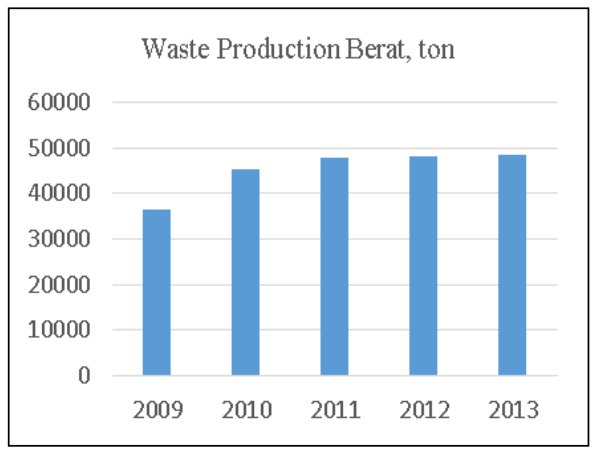
2, fig. 4 .

Table 2 . 
Fig. 4.

According to the experience and scientific literature, safe distances and buffer zones are are created for urban centres, roads, industrial areas, villages, water pipes, gas pipelines, for the purpose of respecting landfill assessment criteria, [8].

During the selection process, two sites have been excluded for geological reasons. The remaining four sites are further studied for all the criterias. From all the known criterias, railways and oil pipelines are exluded. The remainings are;

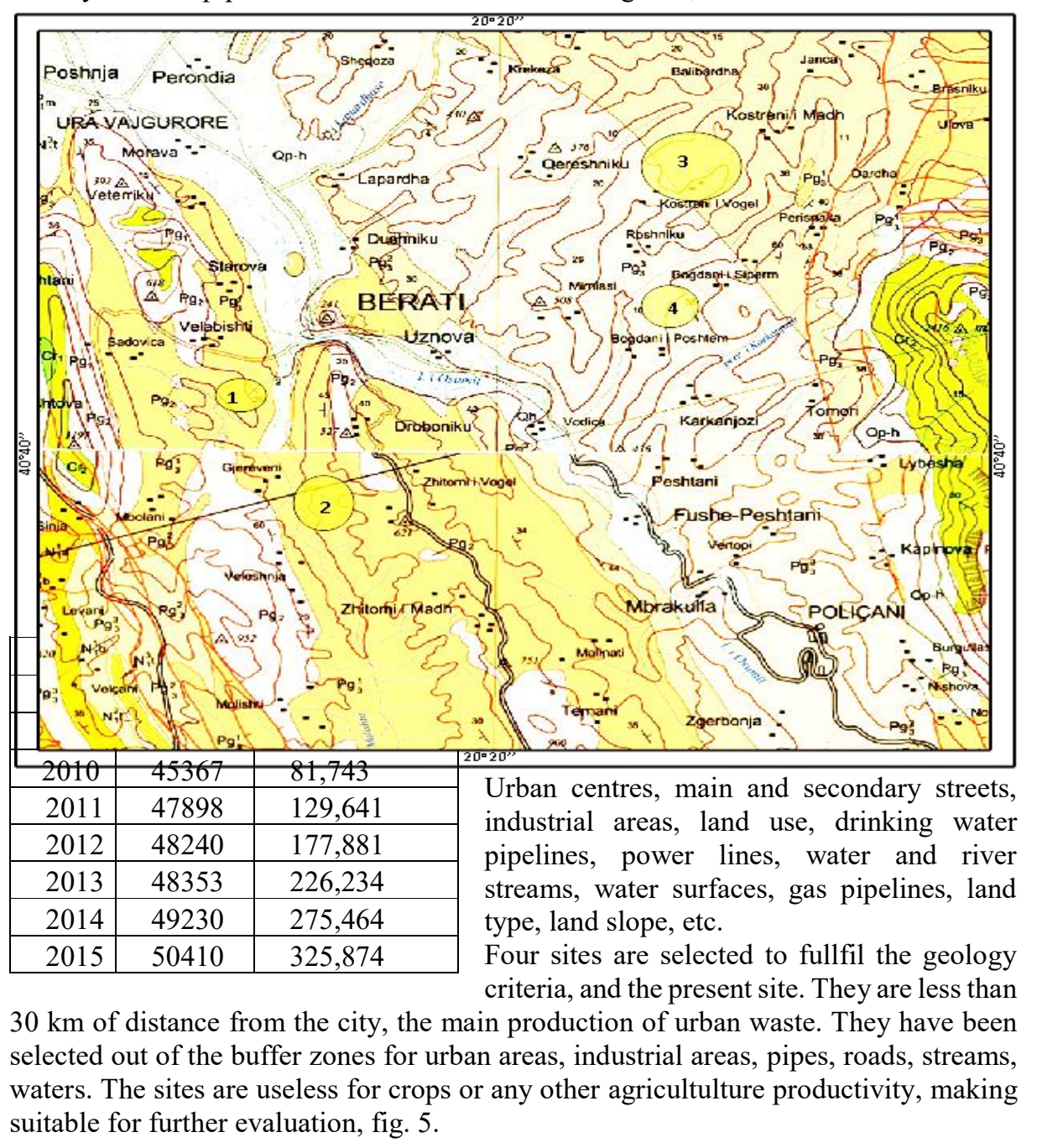

Fig. 5. 


\section{Mathematical model}

As a math model, MCDA model is defined by a set of alternatives, denoted by $A=\{A 1, A 2, \ldots, A m\}$, and a set of criteria, denoted by $C=\{C 1, C 2, \ldots, C n\}$.

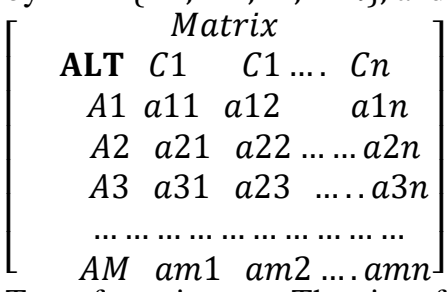

Test of consistency: The aim of this is to determine if the comparisons are consistent or not. It involves following operations:

a) Determine the weighted sum vector by multiplying the weight for the first criterion times the first column of the original pairwise comparison matrix, then multiply the second weight times the second column, the third criterion times the third column of the original matrix, finally sum these values over the rows,

b) Determine the consistenct vector by dividing the weighted sum vector by the criterion weights determined previosly.

c) Compute lanmda $(\lambda)$ which is the average value of the consistenct vector and consistency index (CI) and has the formula below:

$$
C I=\frac{\lambda-n}{n-1}
$$

d) Calculation of the consistency ratio (CR) which is defined as follow:

$C R=\frac{C I}{R I}$

Where RI is the random index and depens on the number of elements being compared. If $C R<0.10$, the ratio indicates a reasonable level of consistency in the pairwise comparison, if $C R>0.10$ tha values indicates incosistent judgement.

Performance matrix is constructed $D=a_{i, j}(m \times n)$, fig. 6 .

The criterias are;

$\mathrm{UR}=$ urban centre, $\mathrm{IN}=$ industrial areas, $\mathrm{ST}=$ streams, $\mathrm{WP}=$ water pipes,

$\mathrm{SW}=$ surface water, $\mathrm{LU}=$ land use, $\mathrm{AE}$ - airport, $\mathrm{ST}=$ soil types, $\mathrm{PL}=$ power lines, $\mathrm{RO}=$ roads, $\mathrm{LG}=$ liquid gas pipes, $\mathrm{SL}=$ slope. 
As a result of AHP application method of pair wise comparison, we have the crireria weights and the matrix, fig. 6 .

Fig. 6. Matrix and the criteria weights.

The final ranking of the landfill sites is calculated by estimating and calculating safe distances from the factors, (buffer zones), table 3.

Table 3. Ranking values calculations.

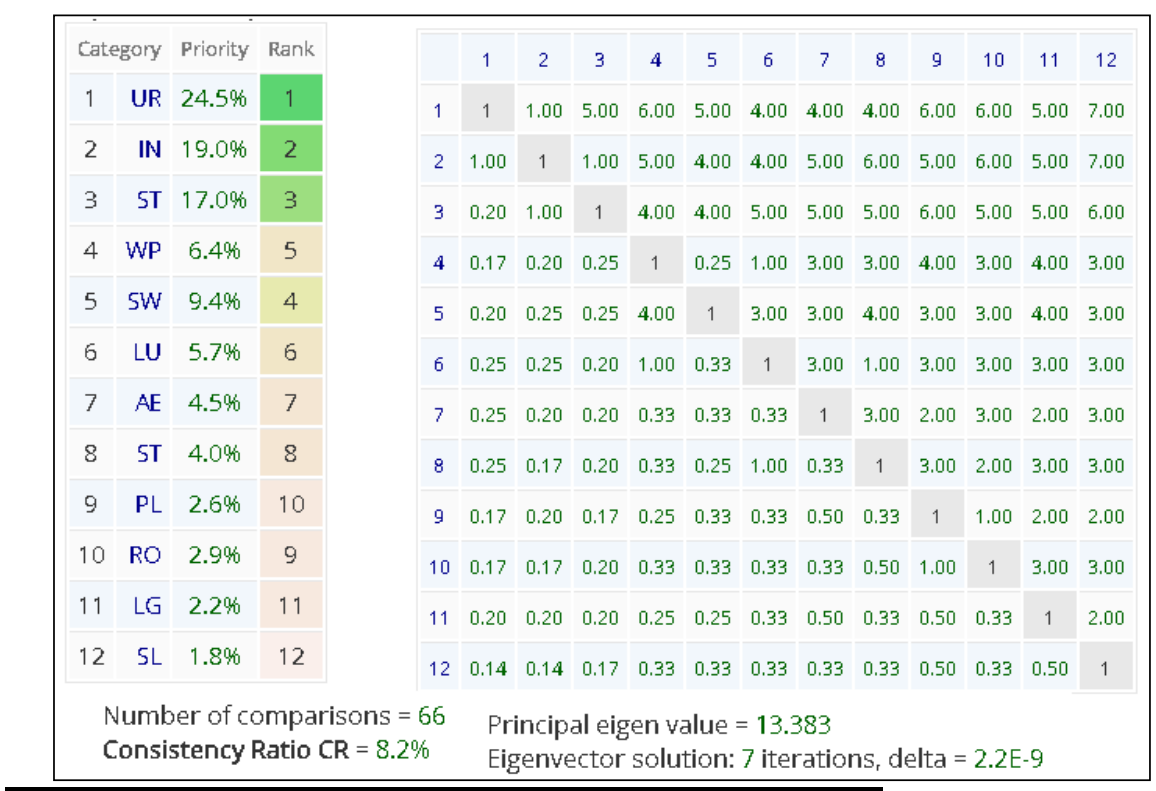

\begin{tabular}{|c|c|c|c|c|c|}
\hline RANK & SITE 0 & SITE 1 & SITE 2 & SITE 3 & SITE 4 \\
\hline UR & 0 & 5 & 6 & 8 & 10 \\
\hline
\end{tabular}




\begin{tabular}{|c|c|c|c|c|c|} 
IN & 0 & 1 & 1 & 1 & 1 \\
\hline ST & 0 & 1 & 1 & 1 & 1 \\
\hline WP & 0 & 2 & 5 & 5 & 5 \\
\hline SW & 0 & 4 & 5 & 5 & 5 \\
\hline LU & 3 & 4 & 5 & 5 & 5 \\
\hline AE & 5 & 5 & 6 & 8 & 8 \\
\hline ST & 2 & 5 & 5 & 5 & 5 \\
\hline PL & 2 & 5 & 5 & 5 & 5 \\
\hline RO & 2 & 5 & 8 & 8 & 10 \\
\hline LG & 2 & 4 & 4 & 5 & 5 \\
\hline SL & 5 & 2 & 2 & 3 & 4 \\
\hline VALUE & 1.75 & 3.58 & 4.42 & 4.92 & 5.33 \\
\hline
\end{tabular}

\section{Conclusion}

The most suitable landfill sites are sites 3,4 . They have suitable geological properties to use as landfill sites for urban waste management. They are in safe distances from urban areas, industrial zones, pipelines, streams, roads, etc. Both sites are suitable to fulfil Berat County needs for landfilling, they are of large areas, they are not far away from main and secondary roads.

Anyway, the county needs a much better local policy of waste management and a much more modern approach from central and local government to deal the urban problems, starting by increasing the recycling percentage, because it is not acceptable to have such a low recycling percentage of less than $10 \%$. Albania ranks among last europian countries in the percentage of recycling.

For the purpose of evaluation and selection of the most suitable landfill sites for urban waste, Mcda and AHP have been proved to be very useful tools to do the job. They are methods of evaluating different alternatives under the conditions to respect all the necessary constraints and criteria for the selection of the best solution.

Further study and evaluation are needed for distant urban centres in order to avoid the not necessary cost of transportation. Other solutions may be small landfill sites to cover local needs.

\section{References}

1. Siddiqui, M.Z., Everett, J.W. and Vieux, B.E. (1996) Landfill Siting Using Geographic Information Systems: A Demonstration. Journal of Environmental Engineering, 122, 515-523. http://dx.doi.org/10.1061/(ASCE)0733-9372(1996)122:6(515).

2. Din, M.A.M., Jaafar, W.Z.W., Markson Obot, R. M. and Wan, M.A.W.H. (2008) How GIS Can Be a Useful Tool to Deal with Landfill Site Selection. International Symposium on Eoinformatics for Spatial Infrastructure Development in Earth and Allied Science, Hanoi, 4-6 December, 1.

3. Saaty, T.L. (1980). The Analytic Hierarchy Process. McGraw-Hill, New York. 
4. Halvadakis, C.P. (1993) Municipal Solid Waste Landfill Siting in Greece-The Case of the Greater Hania Region, Greece. Ekistics, 358, 45-52.

5. Allen, A.R. (2002) Attenuation: A Cost Effective Landfill Strategy for Developing Countries. Proceedings of 9th Congress of the International Association for Engineering Geology and the Environment, Durban, 16-20 September.

6. Allen, A., Brito, G., Caetano, P., Costa, C., Cummins, V., Donelly, J., Fernades, C., Koukoulas, S., O'Donell, V., Robalo, C. and Vendas, D. (2002).

Procedure for the Location of Landfill Sites Using GIS Model. 9th Congress of the International Association of Engineering Geology and the Environment, Durban, 16-20 September, 100.

7. Kontos, T.D., Komillis, D.P. and Halvadakis, C.P. (2003) Siting MSW Landfills in Lesvos Island with a GIS Based Methodology. Waste Management and Research, 21, 262-277. http://dx.doi.org/10.1177/0734242X0302100310

8. Kontos, T.D., Komilis, D.P. and Halvadakis, C.P. (2005) Siting MSW Landfills with Spatial Multiple Criteria Analysis Methodology. Waste Management, 25, 818-832. http://dx.doi.org/10.1016/j.wasman.2005.04.002

9. Kontos, T.D. and Halvadakis, C.P. (2002) Development of a Geographic Information System (GIS) for Land Evaluation for Landfill Siting: The Case of Lemnos Island. 7th National Conference of Hellenic Cartographic Society, Mytilene, 23-26 October.

10. Din, M.A.M., Jaafar, W.Z.W., Markson Obot, R.M. and Wan, M.A.W.H. (2008) How GIS Can Be a Useful Tool to Deal with Landfill Site Selection. International Symposium on Informatics for Spatial Infrastructure Development in Earth and Allied Science, Hanoi, 4-6 December, 1.

11. Chalkias, C.N. and Stournaras, G. (1997) GIS Application for the Selection of Sanitary Waste Disposal Landfills and Quarry Sites in Major Sparti Area, Greece. In: Marinos, K. and Tsiambaos, S., Eds., Engineering Geology and the En- vironment. 